\title{
Metals and tributyltin sediment contamination along the Southeastern Tyrrhenian Sea coast
}

\author{
Giusy Lofrano ${ }^{\mathrm{a}, \mathrm{b}}$, Giovanni Libralato ${ }^{\mathrm{c}, *}$, Aniello Alfieri $^{\mathrm{a}}$, Maurizio Carotenuto ${ }^{\mathrm{a}}$ \\ a Department of Chemistry and Biology, University of Salerno, via Giovanni Paolo II, 132, I-84084 Fisciano (SA), Italy \\ ${ }^{\mathrm{b}}$ Institute of Methodologies for Environmental Analysis, National Research Council (CNR IMA), C. da S. Loja Z.I. Tito Scalo, I-85050, Potenza Italy \\ ${ }^{\mathrm{c}}$ Department of Environmental Sciences, Informatics and Statistics, University Ca' Foscari Venice, Campo della Celestia, 2737/B, I-30122, Venice, Italy
}

\section{H I G H L I G H T S}

- We explored for the first time four sites in the Southeastern Tyrrhenian Sea coast.

- We reviewed sediment quality from other Southern Tyrrhenian Sea sampling sites.

- Sediments from marinas were more impacted than bays by both metals and TBT.

- Risk characterisation ratios exceeded several times the reference site levels.

\section{A R T I C L E I N F O}

\section{Article history:}

Received 15 June 2015

Received in revised form 28 August 2015

Accepted 1 September 2015

Available online 16 September 2015

Handling editor: Martine Leermakers

\section{Keywords:}

Coastal environment

Port

Sediment quality

Metals

TBT

Risk assessment

\begin{abstract}
A B S T R A C T
Anthropogenic pressures can adversely affect the quality of coastal sediment posing at risk human health and the ecosystem. The Southeastern Tyrrhenian Sea (STS) coast (Italy) is still largely unexplored under this point of view. This study investigated for the first time in the area the seasonal variation and potential impact of selected metals $(\mathrm{Cd}, \mathrm{Cr}, \mathrm{Cu}, \mathrm{Ni}$, and $\mathrm{Pb}$ ) and tributyltin (TBT) from sediment samples collected along the STS coast (Casalvelino Marina, Casalvelino Bay, Acciaroli Marina and Acciaroli Bay) in the perspective of Water Framework Directive and Marine Strategy Framework Directive. Data were compared to the contamination background levels of Punta Licosa reference site considering elemental enrichment factors (EFs) and single substance- and mixture-based risk characterisation ratios. Further, data were discussed considering the review of Southern Tyrrhenian Sea sediment quality. Results evidenced an increase of contamination levels from March to October showing that marinas are more impacted than bays. Sediment EFs highlighted that contamination levels were always greater than the reference site like risk characterisation ratios, suggesting the presence of potential threats. The sediment quality database generated after literature review revealed a similar situation for the whole Southern Tyrrhenian Sea.
\end{abstract}

(c) 2015 Elsevier Ltd. All rights reserved.

\section{Introduction}

Marine pollution in coastal areas is a major concern due to the large number of toxic substances discharged (Arizzi Novelli et al., 2006; Libralato et al., 2010a, 2010b; Prato et al., 2015) and accumulated in sediment that act as sink and source of pollution (Wenning and Ingersoll, 2002; Nikolaou et al., 2009; Rzetala, 2015). Especially in harbours and marinas, where exchange of water with

\footnotetext{
* Corresponding author. Department of Environmental Sciences, Informatics and Statistics, University Ca' Foscari Venice, Campo della Celestia, 2737/B, I-30122, Venice, Italy.

E-mail address: giovanni.libralato@unive.it (G. Libralato).
}

the open sea is limited, the accumulation of toxic substances can pose major concerns for human and environmental health such as in presence of recreational waters and mariculture activities (Mamindy-Pajany et al., 2010; Schipper et al., 2010). Frequently, contaminants occur as mixtures showing combined effects, which are still largely unknown (Libralato et al., 2009, 2010). Dredging activities in industrial and commercial ports tend to remobilise sediments as well as the associated pollution through the washing out of both short- and long-term contaminant loadings (Arizzi Novelli et al., 2006; Libralato et al., 2008; Krull et al., 2014; Chakraborty et al., 2014). The assessment of sediment quality is compulsory for the right management of the marine environment as required by 
the Water Framework Directive (2000/60/EC) (WFD) and Marine Strategy Framework Directive (2008/56/EC) (MSFD) that considered sediment as one of the key issue for the proper management of surface water bodies.

Metals and organotin compounds (OTCs) are the most widely occurring contaminants in coastal sediments (Mamindy-Pajany et al., 2010). Metals are naturally present in marine sediment, but their concentration drastically increased due to anthropogenic activities. Tributyltin (TBT) was extensively employed as a biocidal agent in marine antifouling paints. Due to its sub-lethal effects and persistence (Kim et al., 2011; Silva et al., 2014), TBT produced shell calcification anomalies in oyster farming and severe sexual disorders mainly in gastropod species (Kotrikla, 2009; Qiu et al., 2011; Choi et al., 2013; Silva et al., 2014). Since September 2008, the use of TBT-based antifouling paints was restricted in many countries (IMO, 2001). Despite such restrictions, TBT still continues to represent a great environmental problem for marine organisms due to its half-life of about 19 years (Adelman et al., 1990) and its illegal use.

Few studies investigated metals and TBT contamination occurrence in sediment along the Southeastern Italian coast (Cicero et al., 2004; Romano et al., 2004; Ferraro et al., 2006; Tranchina et al., 2008; Romano et al., 2009) and, specifically, the Cilento coast (Sprovieri et al., 2006) that is located southward the Gulf of Salerno $\left(40^{\circ} 20^{\prime} 55^{\prime \prime} \mathrm{N}-14^{\circ} 59^{\prime} 28^{\prime \prime} \mathrm{E}\right.$, and $40^{\circ} 04^{\prime} 23^{\prime \prime} \mathrm{N}-15^{\circ}$ $\left.37^{\prime} 44^{\prime \prime} \mathrm{E}\right)$.

Since 1991, a wide part of Cilento was included in the Cilento, Vallo di Diano e Alburni national park becoming a UNESCO World Heritage Site in 1998. In 2009, the area included the Marine Protected Reserve of Punta Licosa renowned for its water quality. Between 2001 and 2003, the Campania Region Environmental Protection Agency (ARPAC) carried out a broad sediment sampling campaign within the SIDIMAR Project along the Campania Region coast, but sediment samples were mainly collected near river mouths and TBT contamination was not taken into consideration.

This research study investigated the seasonal variation (March and October) of cadmium (Cd), chromium $(\mathrm{Cr})$, copper $(\mathrm{Cu})$, nickel $(\mathrm{Ni})$, lead $(\mathrm{Pb})$ and TBT in sediment samples collected from four sampling sites located along the Cilento coast. These pollutants, due to their potential adverse effects on human health and the environment, were further explored reviewing the existing information on sediment contamination falling in the Southeastern Tyrrhenian Sea in the perspective of the WFD and MSFD. The environmental risk of sediments was evaluated considering the potential effects of substances taken singly and as a mixture, providing the state-of-the-art scenario of the contamination in the study area compared to the reference site of Punta Licosa.

\section{Materials and methods}

\subsection{Sampling and sediment collection}

Sediment samples were collected in Casalvelino Marina $\left(40^{\circ} 10^{\prime}\right.$ $\left.31^{\prime \prime} \mathrm{N}-15^{\circ} 07^{\prime} 14^{\prime \prime} \mathrm{E}\right)$, Casalvelino Bay (40 $10^{\prime} 10^{\prime \prime} \mathrm{N}-15^{\circ} 07^{\prime}$ $\left.58^{\prime \prime} \mathrm{E}\right)$, Acciaroli Marina ( $\left.40^{\circ} 10^{\prime} 39^{\prime \prime} \mathrm{N}-15^{\circ} 01^{\prime} 39^{\prime \prime} \mathrm{E}\right)$ and Acciaroli Bay $\left(40^{\circ} 11^{\prime} 07^{\prime \prime} \mathrm{N}-15^{\circ} 01^{\prime} 21^{\prime \prime} \mathrm{E}\right)$ (Fig. 1). For marinas, sampling activities took place inside the harbour area, while for bays at $100 \mathrm{~m}$ from the coast. Punta Licosa (Fig. 1) was considered as the reference site for sediment according to ARPAC (2003).

Seasonal variability in sediment characteristics (i.e. marine traffic and weather conditions) was checked according to two sampling campaigns (March 2010, October 2010). About $1 \mathrm{~kg}$ of surface sediment (5 $\mathrm{cm}$ top layer) was collected in each sampling site with an Ekman box corer after the on site integration of four sampling replicates. After reducing excess water, sediment sam- ples were stored into polyethylene bags and refrigerated at $4{ }^{\circ} \mathrm{C}$ in the dark. Once in the laboratory (in no more than $5 \mathrm{~h}$ after collection), coarse materials was removed (e.g. shells and organic residues) and aliquots of homogenised specimen were dried for $2 \mathrm{~h}$ at room temperature and, subsequently, in an oven at $105^{\circ} \mathrm{C}$ for at least $24 \mathrm{~h}$. Dried sediments were sieved ( $2 \mathrm{~mm}$ mesh) and grounded in a corundum mortar. Pre-treated samples were kept frozen at $-20{ }^{\circ} \mathrm{C}$ up to the analysis that was carried out in triplicate (ICRAM-APAT, 2007).

\subsection{Reagents and materials}

Ultrapure $\mathrm{HCl}$ (33\%) (Carlo Erba, Germany) and $\mathrm{HNO}_{3}$ (69\%) (Fluka Trace Select), and ultra-pure deionised water (Elix 10, Merck Millipore, Billarica, MA, USA) were used for the preparation of standard solutions and samples. All chemicals were of analytical grade. Standard calibration solutions of $\mathrm{Cd}, \mathrm{Cr}, \mathrm{Cu}, \mathrm{Ni}$, and $\mathrm{Pb}$ (Sigma-Aldrich, St. Louis, MO, USA) were prepared in acid water $\left(\mathrm{HNO}_{3} 1 \%\right)$ starting from standard stock solutions $(1000 \mathrm{mg} / \mathrm{L})$. Laboratory plasticware and glassware for analytical purposes were cleaned with $\mathrm{HNO}_{3} 2 \%$ and rinsed with abundant deionized water before use. The accuracy of the applied analytical methods was checked on Certified Reference Materials BCR 320R and BCR 646 from European Commission - Joint Research Centre (EC-JRC).

\subsection{Sample preparation and analysis}

Metal concentrations $(\mathrm{Cd}, \mathrm{Cr}, \mathrm{Cu}, \mathrm{Ni}$, and $\mathrm{Pb})$ were determined in triplicate according to ICRAM-APAT (2007) by Atomic Absorption Spectroscopy (AAS). The Limit of Detection (LOD) and Limit of Quantification (LOQ) in $\mu \mathrm{g} \mathrm{g}^{-1}$ were 0.034 and 0.113 for $\mathrm{Cd}, 0.815$ and 2.718 for $\mathrm{Cr}, 1.000$ and 3.400 for $\mathrm{Cu}, 0.860$ and 2.854 for $\mathrm{Ni}$, and 0.140 and 5.000 for $\mathrm{Pb}$. The analysis of TBT as Sn was carried out by 757 VA Computrace polarograph (Metrohm, Origgio, Italy) $\left(\operatorname{LOD}(\mathrm{Sn})=0.5 \mathrm{ng} \mathrm{g}^{-1}\right)$. Details of chemicals characterizations were reported in Supplementary Materials.

\subsection{Data analysis}

The significance of differences between mean concentration values was assessed by the analysis of variance (ANOVA) considering a significance threshold level always set at $5 \%$. When ANOVA revealed significant differences among treatments, post-hoc tests were carried out with Dunnett's and Tukey's tests. The relationship between variables and the variation present in the dataset matrix were accounted via biplotting both the ordination component scores and the variable loading coefficients through principal component analysis (PCA) (Pearson's correlation matrix). Statistical analyses were performed using Microsoft ${ }^{\circledR}$ Excel 2013/XLSTAT@Pro (Version 7.2, 2003, Addinsoft, Inc., Brooklyn, NY, USA).

\subsection{Enrichment factors and risk assessment}

In order to assess the rate of contamination and potential sources of anthropogenic inputs to the marine environment, enrichment factors (EFs) were calculated for each metal and TBT using the Equation (1), where $[\mathrm{M}]_{\mathrm{S}}$ is the metal concentration of the sample and $[\mathrm{M}]_{\text {ref }}$ is the concentration of the same metal in the reference area (Punta Licosa) as reported in Table S2. According to this equation, a result $\leq 0$ indicates no metal enrichment in the sample, while values $>0$ indicate a metal enrichment in the sample with respect to the control area (Tranchina et al., 2008).

$\mathrm{EFs}=\left(\frac{[\mathrm{M}]_{\mathrm{s}}}{[\mathrm{M}]_{\mathrm{ref}}}-1\right) \times 100$ 


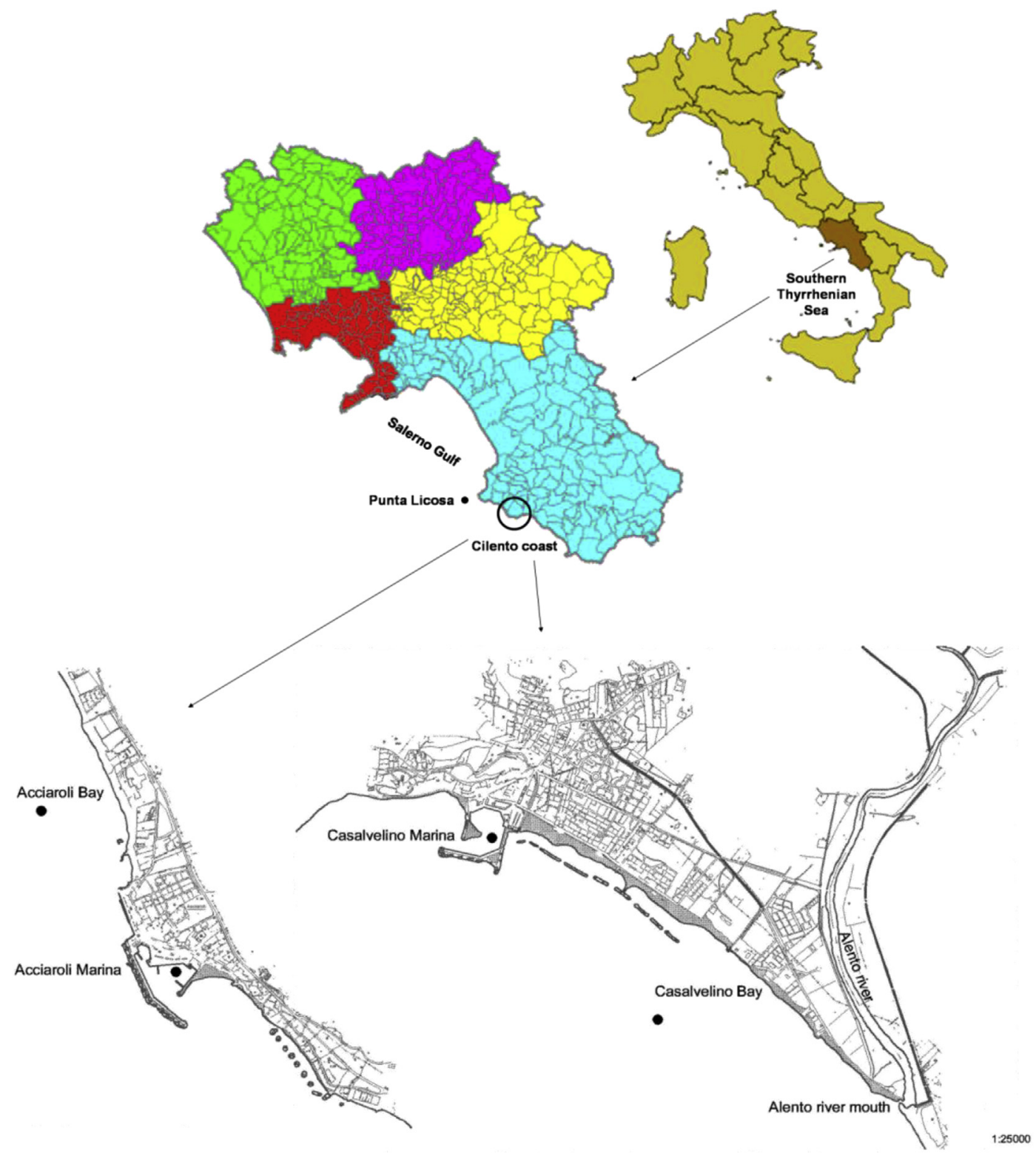

Fig. 1. Sampling (Acciaroli Marina, Acciaroli Bay, Casalvelino Marina and Casalvelino Bay) and reference (Punta Licosa) sites along the Southern Tyrrhenian Sea.

In the perspective of an environmental risk assessment, metals and TBT concentrations measured in this study like those reported by other authors (Table 1 and Table S2) along the Southern Tyrrhenian coasts were compared to three quality standards: Environment Canada-Threshold Effect Level (EC-TEL), Environmental Quality Standards (EQSs) and Ecotoxicological Assessment Criteria (EAC) (Table S3). EC-TEL, EQS and EACs are suggested by the Canadian Marine Sediment Quality Guidelines (1999), Shiga Prefecture (2001), and OSPAR (2004), respectively.

According to Ghekiere et al. (2013), the risk characterization ratio of a single pollutant (RCR) was carried out using Equation (2), where MEC is the Measured Environmental/Exposure Concentration. On the basis of the worst-case scenario approach, the selected MEC value was the highest one measured during the sampling period. If RCR was larger or equal to 1 a potential environmental risk was expected.

$\mathrm{RCR}=\frac{\mathrm{MEC}}{\mathrm{EC}-\mathrm{TEL}}$ or $\frac{\mathrm{MEC}}{\mathrm{EQS}}$ or $\frac{\mathrm{MEC}}{\mathrm{EAC}}$
For the risk assessment of pollutants as a mixture, the concentration addition approach was taken into consideration. If the value of the risk characterization ratio of the mixture $\left(R_{C} R_{m}\right)$ calculated from Equation (3) was larger or equal to 1 a potential environmental risk was expected.

$\mathrm{RCR}_{\mathrm{m}}=\sum_{i=1}^{n} \mathrm{RCR}_{\mathrm{i}}=\sum_{i=1}^{n} \frac{\mathrm{MEC}_{\mathrm{i}}}{\mathrm{EC}-\mathrm{TEL}_{\mathrm{i}}}$ or $\sum_{i=1}^{n} \frac{\mathrm{MEC}_{\mathrm{i}}}{\mathrm{EQS}_{\mathrm{i}}}$ or $\sum_{i=1}^{n} \frac{\mathrm{MEC}_{\mathrm{i}}}{\mathrm{EAC}_{\mathrm{i}}}$

\section{Results and discussion}

The concentration of metals $(\mathrm{Cd}, \mathrm{Cr}, \mathrm{Cu}, \mathrm{Ni}$, and $\mathrm{Pb})$ and TBT in bays and marinas were generally higher in October than in March (Fig. 2). The values detected in bays in March were similar to those of the reference site (Punta Licosa), varying significantly only for $\mathrm{Cr}$ (Fig. 2B). Within the October sampling, significant differences were observed for Ni (Fig. 2D), Cr (Fig. 2B) and Pb (Fig. 2E). Except for $\mathrm{Cd}$ (Fig. 2A), the concentrations of metals from sediment collected in March were similar in both marinas. The highest Cd concentra- 
Table 1

TBT sediment concentrations as Sn (ng g-1 d.w.) from the Southern Tyrrhenian coast.

\begin{tabular}{|c|c|c|c|c|c|}
\hline Sampling sites & & Location & TBT (ng Sn g ${ }^{-1}$ d.w.) & Campaign & Reference \\
\hline \multirow[t]{12}{*}{ Gulf of Naples } & \multirow[t]{2}{*}{ S1 } & $40^{\circ} 48.553^{\prime} \mathrm{N}$ & 17.81 & \multirow[t]{12}{*}{ July 1999} & \multirow{12}{*}{ Cicero et al. (2004) } \\
\hline & & $14^{\circ} 12.744^{\prime} \mathrm{E}$ & & & \\
\hline & \multirow[t]{2}{*}{ S2 } & $40^{\circ} 48.630^{\prime} \mathrm{N}$ & 15.79 & & \\
\hline & & $14^{\circ} 12.841^{\prime} \mathrm{E}$ & & & \\
\hline & \multirow[t]{2}{*}{ S3 } & $48^{\circ} 48.782^{\prime} \mathrm{N}$ & 15.31 & & \\
\hline & & $14^{\circ} 13.574^{\prime} \mathrm{E}$ & & & \\
\hline & \multirow[t]{2}{*}{ S4 } & $40^{\circ} 49.000^{\prime} \mathrm{N}$ & 16.28 & & \\
\hline & & $14^{\circ} 14.300^{\prime} \mathrm{E}$ & & & \\
\hline & \multirow[t]{2}{*}{ S5 } & $40^{\circ} 48.884^{\prime} \mathrm{N}$ & 14.84 & & \\
\hline & & $14^{\circ} 19.370^{\prime} \mathrm{E}$ & & & \\
\hline & \multirow[t]{2}{*}{ S6 } & $40^{\circ} 48.490^{\prime} \mathrm{N}$ & 15.03 & & \\
\hline & & $14^{\circ} 19.090^{\prime} \mathrm{E}$ & & & \\
\hline \multirow[t]{4}{*}{ Gulf of Salerno } & \multirow[t]{2}{*}{ S7 } & $40^{\circ} 34.311^{\prime} \mathrm{N}$ & 10.47 & \multirow[t]{4}{*}{ July 1999} & Cicero et al. (2004) \\
\hline & & $14^{\circ} 50.301^{\prime} \mathrm{E}$ & & & \\
\hline & \multirow[t]{2}{*}{ S8 } & $40^{\circ} 23.618^{\prime} \mathrm{N}$ & 10.80 & & Cicero et al. (2004) \\
\hline & & $14^{\circ} 56.192^{\prime} \mathrm{E}$ & & & \\
\hline \multirow[t]{2}{*}{ Acciaroli Marina (Cilento) } & \multirow[t]{2}{*}{ S9 } & $40^{\circ} 10.651^{\prime} \mathrm{N}$ & $93 \pm 2$ & March 2010 & \multirow[t]{2}{*}{ This study } \\
\hline & & $15^{\circ} 01.640^{\prime} \mathrm{E}$ & $344 \pm 80$ & October 2010 & \\
\hline \multirow[t]{2}{*}{ Acciaroli Bay (Cilento) } & \multirow[t]{2}{*}{ S10 } & $40^{\circ} 10.974^{\prime} \mathrm{N}$ & $1.55 \pm 0.06$ & October 2010 & \multirow[t]{2}{*}{ This study } \\
\hline & & $15^{\circ} 01.344^{\prime} \mathrm{E}$ & & & \\
\hline \multirow[t]{2}{*}{ Casalvelino Marina (Cilento) } & \multirow[t]{2}{*}{ S11 } & $40^{\circ} 10.535^{\prime} \mathrm{N}$ & $6 \pm 2$ & March 2010 & \multirow[t]{2}{*}{ This study } \\
\hline & & $15^{\circ} 07.251^{\prime} \mathrm{E}$ & $7 \pm 2$ & October 2010 & \\
\hline \multirow[t]{2}{*}{ Casalvelino Bay (Cilento) } & \multirow[t]{2}{*}{ S12 } & $40^{\circ} 10.013^{\prime} \mathrm{N}$ & $0.83 \pm 0.01$ & March 2010 & \multirow[t]{2}{*}{ This study } \\
\hline & & $15^{\circ} 07.813^{\prime} \mathrm{E}$ & $1.57 \pm 0.07$ & October 2010 & \\
\hline \multirow[t]{4}{*}{ Gulf of Policastro (Cilento) } & \multirow[t]{2}{*}{ S13 } & $40^{\circ} 03.346^{\prime} \mathrm{N}$ & 8.02 & \multirow[t]{4}{*}{ July 1999} & \multirow[t]{4}{*}{ Cicero et al. (2004) } \\
\hline & & $15^{\circ} 31.053^{\prime} \mathrm{E}$ & & & \\
\hline & S14 & $40^{\circ} 02.999^{\prime} \mathrm{N}$ & 7.41 & & \\
\hline & & $15^{\circ} 31.516^{\prime} \mathrm{E}$ & & & \\
\hline Gulf of Santa Eufemia & S15 & $38^{\circ} 52.715^{\prime} \mathrm{N}$ & 7.33 & July 1999 & Cicero et al. (2004) \\
\hline & & $16^{\circ} 12.841^{\prime} \mathrm{E}$ & & & \\
\hline & S16 & $38^{\circ} 52.619^{\prime} \mathrm{N}$ & 7.23 & & \\
\hline & & $16^{\circ} 11.989^{\prime} \mathrm{E}$ & & & \\
\hline North-Western Sicilian coasts and Ustica & S17 & - & $3-27$ & July-November 1999 & Chiavarini et al. (2003) \\
\hline & & & & May-June 2000 & \\
\hline
\end{tabular}

tions were detected in Casalvelino Marina, where a significant increase was observed between the two sampling campaigns from $0.32 \mu \mathrm{g} \mathrm{g}^{-1}$ to $0.49 \mu \mathrm{g} \mathrm{g}^{-1}$ from March to October, respectively. Conversely, Cd concentration was significantly lower in Acciaroli Marina $\left(0.32 \mu \mathrm{g} \mathrm{g}^{-1}\right)$. According to Table S2, the highest Cd concentrations along the Southeastern Tyrrhenian Sea $\left(0.57 \mu \mathrm{g} \mathrm{g}^{-1}\right)$ were detected in the Gulf of Bagnoli (Naples). Compared to all other monitored elements along Southeastern Tyrrhenian Sea, Cd presented the lowest concentrations ever.

Significant differences in $\mathrm{Cr}$ (Fig. 2B) concentrations were evidenced between March and October samplings in both marinas. The highest $\mathrm{Cr}$ concentration $\left(50.20 \mu \mathrm{g} \mathrm{g}^{-1}\right)$ was measured in Acciaroli Marina in October. This value was comparable to $\mathrm{Cr}$ concentration (52.49 $\mathrm{M} \mathrm{g} \mathrm{g}^{-1}$ ) (Table S2) detected in Palermo city port. Other $\mathrm{Cr}$ hot spots along the Campania coast were observed at the Sarno River mouth $\left(84.40 \mu \mathrm{g} \mathrm{g}^{-1}\right.$ ) (Table S2) and Naples city port (72.50 $\mu \mathrm{g} \mathrm{g}^{-1}$ ) (Table S2). The concentration of $\mathrm{Cu}$ (Fig. 2C) in Acciaroli Marina in October (492.6 $\mathrm{g} \mathrm{g} \mathrm{g}^{-1}$ ) was significantly higher than in Casalvelino Marina $\left(218 \mu \mathrm{g} \mathrm{g}^{-1}\right)$ and the maximum concentration detected along the Southeastern Tyrrhenian Sea (Palermo city port, $223.06 \mu \mathrm{g} \mathrm{g}^{-1}$ ) (Table S2). A significant increase of $\mathrm{Cu}$ concentration was recorded between March and October samplings in Acciaroli Marina. Seasonal fluctuations in $\mathrm{Ni}$ concentrations were observed (Fig. 2D), but with no significant differences between the two marinas. In October, the concentration of $\mathrm{Ni}$ in Casalvelino Marina $\left(46 \mu \mathrm{g} \mathrm{g}{ }^{-1}\right.$ ) was higher than those detected along the Southern Italian coast ranging between $2.80 \mu \mathrm{g} \mathrm{g}^{-1}$ (Punta Licosa) and $16.60 \mu \mathrm{g} \mathrm{g}^{-1}$ (Sarno River) (Table S2). The concentration of Pb (Fig. 2E) did not vary significantly between both marinas and the reference site, except for Casalvelino Marina during October $\left(129 \mu \mathrm{g} \mathrm{g}^{-1}\right)$. The concentra- tion of $\mathrm{Cd}$ and $\mathrm{Pb}$ in both marinas was significantly higher than those reported for sediment collected in Northern Adriatic Sea marinas (0.068 $\mu \mathrm{g} \mathrm{Cd} \mathrm{g}^{-1}, 14 \mu \mathrm{g} \mathrm{Pb} \mathrm{g}^{-1}$ ) (Scancar et al., 2007). Their increase in October suggested a potential significant anthropogenic input from summertime leisure activities. Lead in Acciaroli Bay (699 $\mu \mathrm{g} \mathrm{g}^{-1}$ ) was higher than the concentrations detected in both marinas (129 $\mu \mathrm{g} \mathrm{g}^{-1}$ in Casalvelino Marina and $11.9 \mu \mathrm{g} \mathrm{g}^{-1}$ in Acciaroli Marina) and in all sediments collected along Southern Tyrrhenian coast as reported in Table S2. The concentration of $\mathrm{Pb}$ observed in Acciaroli Marina was lower than that measured in areas from the Southern Italian coast considered as reference sites such as the Gulf of Termini Imerese (Palermo) (Table S2). According to Table $\mathrm{S} 2, \mathrm{~Pb}$ resulted the main contaminant present in $\mathrm{Pi}$ azza Vittoria (Naples) sampling station. Frequently, $\mathrm{Pb}$ is present in antifouling paints, fuels and batteries thus being release also by pleasure boats (Almeida et al., 2007).

In Acciaroli Marina, a significant difference in TBT concentration was evidenced between March (93 $\mu \mathrm{g} \mathrm{g}^{-1}$ ) and October (344 $\mu \mathrm{g} \mathrm{g}^{-1}$ ) (Fig. 2F) compared to all other investigated sites. The contamination could be due to recent resuspension phenomena of contaminated sediment (boat mechanical resuspension, dredging operations, and sludge dumping), port construction activities and/or illegal use of TBT-based antifouling paints. Lower concentrations of TBT were found in Casalvelino Marina with no seasonal variability. Acciaroli Marina compared to Casalvelino Marina presents docking activities and boatyard. The TBT concentration of Acciaroli Marina sediment was higher than other sites investigated along the Southern Tyrrhenian Sea (Table 1), but none of the sampling stations was located inside a port. Other marinas around the world presented similar contamination levels: 46.2-3935 ng Sn g-1 in United Kingdom (Dowson et al., 1992), 25 ng Sn g-1 in Portugal 

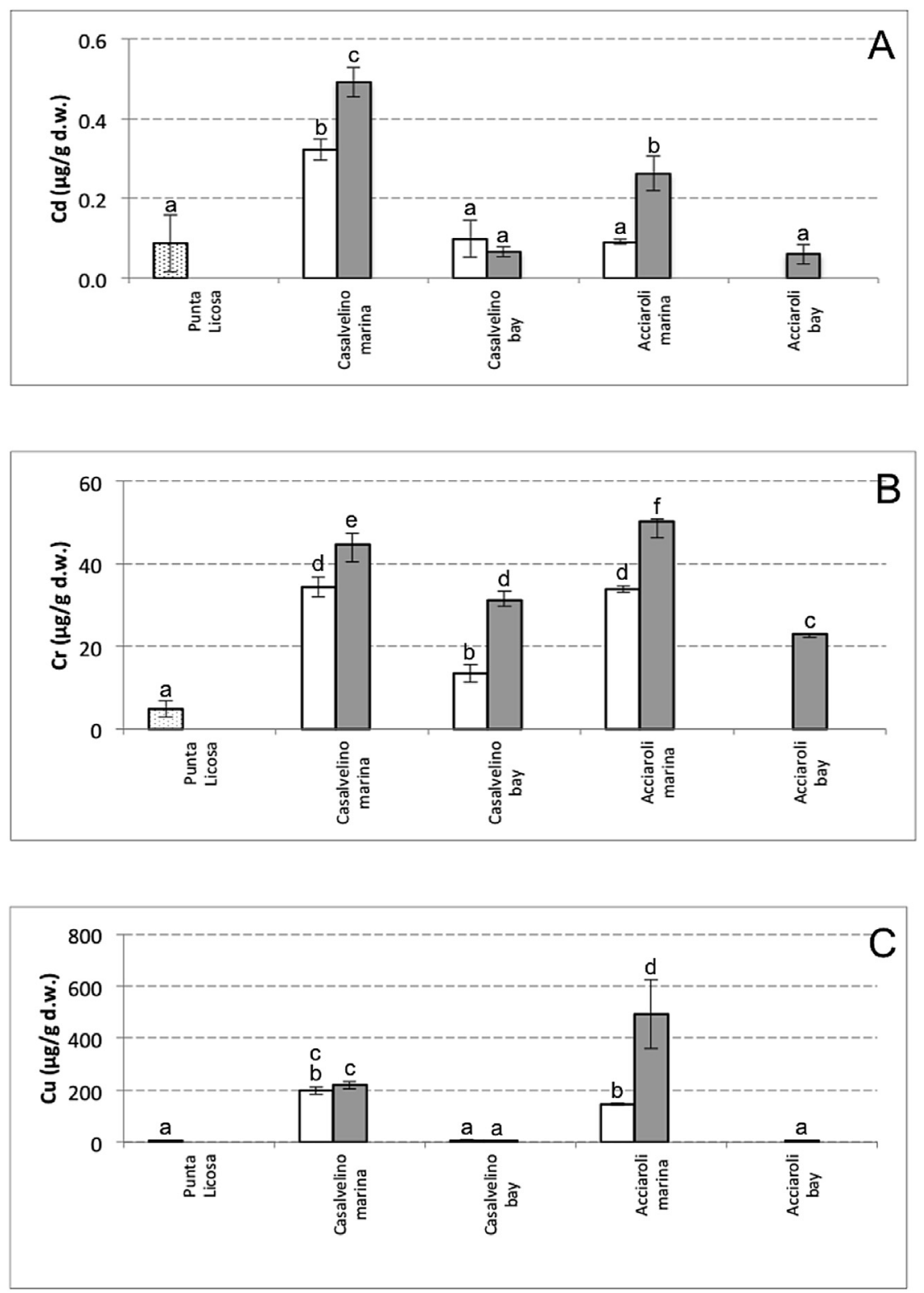

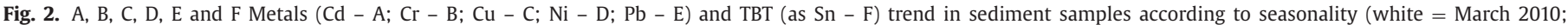

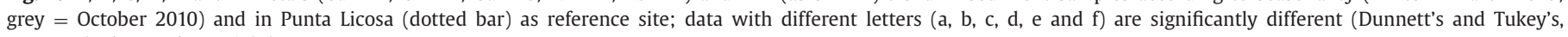
$\mathrm{p}<0.05$ ); d.w. = dry weight).

(Sousa et al., 2007), 920-975 ng Sn $\mathrm{g}^{-1}$ in Spain (Diez et al., 2002), and 100-780 ng Sn $\mathrm{g}^{-1}$ in Slovenia (Scancar et al., 2007). The berthing capacity and ship traffic in the two marinas could explain the highest $\mathrm{Cu}, \mathrm{Pb}$, and TBT levels measured in Acciaroli Marina (460 berths) compared to Casalvelino Marina (120 berths). A similar high concentrations for $\mathrm{Cu}\left(698 \mu \mathrm{g} \mathrm{g}^{-1}\right)$ and $\mathrm{Pb}\left(220 \mu \mathrm{g} \mathrm{g}^{-1}\right)$ were detected in marine sediments of Palermo Gulf, collected inside the Cala Area that is an enclosed zone in which the circulation of water is restricted and domestic sewage coming from the city of Palermo is free to flow (Tranchina et al., 2008).

About the environmental risk assessment, several guidelines were developed dealing with contaminated sediment in response to regulatory requirements (Bay and Weisberg, 2012). For each substance, the MEC was compared to three quality standards for metals (Table 2) and TBT (Table 3). Furthermore, As, Cd, Cu, Cr, $\mathrm{Hg}, \mathrm{Pb}, \mathrm{Ni}$, and $\mathrm{Zn}$ (Table 2), and TBT (Table 3) risk characterisation were investigated for other sampling sites located along the
Southeastern Tyrrhenian Sea coast (ARPAC, 2003, 2007; Chiavarini et al., 2003; Cicero et al., 2004; Ferraro et al., 2006; Tranchina et al., 2008; Romano et al., 2009). Threshold values for EQS and EAC (Table S3) were exceeded for several metals and TBT. In most cases, RCR values of single pollutants were larger than 1 suggesting the occurrence of potential environmental risks. Sediment from port areas was the most impacted like in Naples and Palermo (Table 2). The highest RCR values for Cd (MEC/EC-TEL $=1.32$, $\mathrm{MEC} / \mathrm{EAC}=9$ and $\mathrm{MEC} / \mathrm{EQS}=90)$ and for $\mathrm{Hg}(\mathrm{MEC} / \mathrm{EC}-\mathrm{TEL}=10.1$, $\mathrm{MEC} / \mathrm{EAC}=26.4$ and $\mathrm{MEC} / \mathrm{EQS}=2640)$ were observed in Naples city port and in Palermo city port, respectively; for Zn (MEC/EC$\mathrm{TEL}=4.85, \mathrm{MEC} / \mathrm{EAC}=12.04)$ in Gulf of Bagnoli. Other sediment hot spots were detected at the river mouth of heavily contaminated rivers like the Sarno River (Lofrano et al., 2015). The highest RCR values for Cr (MEC/EC-TEL of 1.61, MEC/EAC of 8.44 and $\mathrm{MEC} / \mathrm{EQS}$ of 1688) were observed in Sarno River. Due to the volcanic origin of the Campania Region coast, the presence of high 

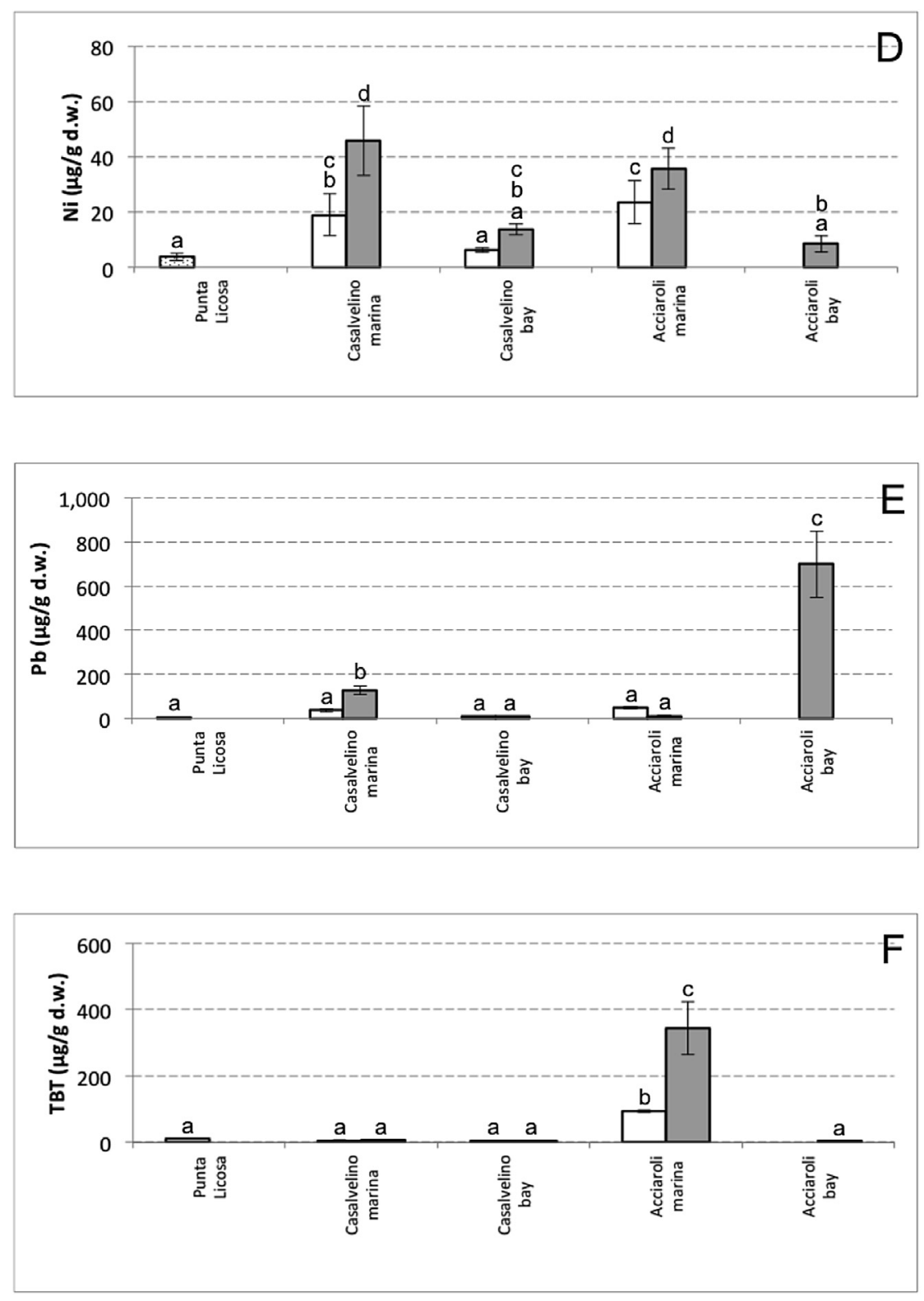

Fig. 2. Continued

RCR values for As was expected (MEC/EC-TEL of 3.16, of MEC/EAC 22.90 and $\mathrm{MEC} / \mathrm{EQS}$ of 2290) like in Punta Tresino that is frequently assumed as a reference site. The highest RCR values for $\mathrm{Cu}(\mathrm{MEC} / \mathrm{EC}-\mathrm{TEL}=26, \mathrm{MEC} / \mathrm{EAC}=99), \mathrm{Pb}(\mathrm{MEC} / \mathrm{EC}-\mathrm{TEL}=23$, $\mathrm{MEC} / \mathrm{EAC}=140$ and $\mathrm{MEC} / \mathrm{EQS}=69,934)$, Ni $(\mathrm{MEC} / \mathrm{EC}-\mathrm{TEL}=2.88$, $\mathrm{MEC} / \mathrm{EAC}=9.16)$ were observed in Acciaroli Marina, Acciaroli Bay and Casalvelino Marina, respectively.

The risk associated to TBT was high for Acciaroli Marina with values up to 23-fold greater than the Gulf of Naples (Table 3). Data from Casalvelino Marina were similar to other Cilento coastal sampling sites like in the Gulf of Policastro and Santa Eufemia (Cicero et al., 2004). For TBT, the lowest RCR values were found in Casalvelino Bay and Acciaroli Bay. Unfortunately, no reference site (Punta Licosa) data on TBT are currently available thus the potential background level remains still unknown.

To date, no EU guidelines are available to address both human health and environmental assessment of chemical mixtures. Experimental mixture studies in ecotoxicology and human toxicol- ogy demonstrated that the concept of dose/concentration addition and independent action provide good approximations of observed combination effects (Kortenkamp, 2007). From data in Tables 2 and 3, the risk assessment of mixtures was investigated according to the concentration addition approach. Frequently, the RCRs exceeded the threshold value for the single substance along the Cilento coast. As consequence, the risk assessment of mixtures leads to even higher potential risks. Although in Punta Licosa most RCRs showed values lower than 1 , the relative $R C R_{m}$ value was $>1$. This was mainly due to arsenic (not investigated in our study) that is of geogenic origin leading to overestimate the $\mathrm{RCR}_{\mathrm{m}}$ in the reference area. For this reason, regional guidelines taking into consideration the specific biogeochemical characteristics of the area should be developed to carry out site-specific risk analysis avoiding misjudgements (Ghekiere et al., 2013).

The PCA analysis (Fig. 3) clustered together Acciaroli Bay and Casalvelino Bay with Punta Licosa reference site due to their low contamination level. Both marinas showed to be impacted, 
Table 2

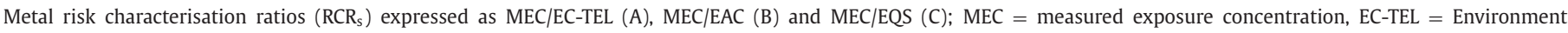
Canada-Threshold Effect Level, EAC = Ecotoxicological Assessment Criteria, EQS = Environmental Quality Guidelines and.

\begin{tabular}{|c|c|c|c|c|c|c|c|c|c|c|c|c|}
\hline \multicolumn{2}{|l|}{ Sampling sites } & $\mathrm{RCR}_{\mathrm{s}}$ & As & $\mathrm{Cd}$ & $\mathrm{Cu}$ & $\mathrm{Cr}$ & $\mathrm{Hg}$ & $\mathrm{Pb}$ & $\mathrm{Ni}$ & $\mathrm{Zn}$ & $\mathrm{RCR}_{\mathrm{m}}$ & References \\
\hline \multirow{3}{*}{\multicolumn{2}{|c|}{ Volturno River (Campania) }} & A & 0.69 & 0.29 & 0.71 & 0.51 & 1.84 & 0.43 & 1.02 & 0.27 & 6 & ARPAC $(2003,2007)$ \\
\hline & & B & 5 & 2 & 2.68 & 2.69 & 4.8 & 2.6 & 3.26 & 0.66 & 24 & \\
\hline & & $\mathrm{C}$ & 500 & 20 & - & 538 & 480 & 1300 & - & - & 2838 & \\
\hline \multirow{3}{*}{\multicolumn{2}{|c|}{ Gulf of Bagnoli (Campania) }} & A & 0.28 & 0.84 & 1.44 & 0.53 & 5.38 & 7.3 & 0.43 & 4.85 & 21 & Romano et al. (2009) \\
\hline & & $\mathrm{B}$ & 2 & 5.70 & 5.44 & 2.80 & 14 & 44.22 & 1.38 & 12.04 & 88 & \\
\hline & & $\mathrm{C}$ & 200 & 57 & - & 560 & 1400 & 22,100 & - & - & 24,317 & \\
\hline \multirow[t]{12}{*}{ Gulf of Naples (Campania) } & \multirow{3}{*}{ Naples city port } & A & 2.17 & 1.32 & 7 & 1.38 & - & 4.1 & - & 2.44 & 19 & Ferraro et al. (2006) \\
\hline & & B & 15.70 & 9 & 26.2 & 7.25 & - & 24.6 & - & 6.06 & 92 & \\
\hline & & $\mathrm{C}$ & 1570 & 90 & - & 1450 & - & 12,300 & - & - & 15,410 & \\
\hline & \multirow[t]{3}{*}{ Piazza Vittoria } & A & 1.89 & 0.26 & 0.7 & 0.24 & 3.31 & 2.9 & 0.95 & 0.62 & 11 & ARPAC $(2003,2007)$ \\
\hline & & B & 13.70 & 1.80 & 2.8 & 1.26 & 8.6 & 17.38 & 3.04 & 1.53 & 50 & \\
\hline & & $\mathrm{C}$ & 1370 & 18 & - & 252 & 860 & 8690 & - & - & 11,190 & \\
\hline & \multirow[t]{3}{*}{ Portici } & A & 1.80 & 0.22 & 1.5 & 0.34 & 1.92 & 0.66 & 1.01 & 0.45 & 8 & \\
\hline & & $\mathrm{B}$ & 13 & 1.5 & 5.64 & 1.78 & 5 & 4.02 & 3.24 & 1.11 & 35 & \\
\hline & & $\mathrm{C}$ & 1300 & 15 & - & 356 & 500 & 2010 & - & - & 4181 & \\
\hline & \multirow[t]{3}{*}{ Sarno River } & A & 1.12 & 0.53 & 2.7 & 1.61 & 2.15 & 1.92 & 1.04 & 0.45 & 12 & \\
\hline & & B & 8.10 & 3.60 & 10.1 & 8.44 & 5.6 & 11.64 & 3.32 & 1.11 & 52 & \\
\hline & & $\mathrm{C}$ & 810 & 36 & - & 1688 & 560 & 5820 & - & - & 8914 & \\
\hline \multirow[t]{6}{*}{ Gulf of Salerno (Campania) } & \multirow{3}{*}{ Picentino river } & A & 0.80 & 0.22 & 0.24 & 0.26 & 2.15 & 0.22 & 0.71 & 0.55 & 5 & ARPAC $(2003,2007)$ \\
\hline & & B & 5.80 & 1.5 & 0.92 & 1.41 & 5.6 & 1.38 & 2.26 & 1.37 & 20 & \\
\hline & & $\mathrm{C}$ & 580 & 15 & - & 282 & 560 & 690 & - & - & 2127 & \\
\hline & \multirow[t]{3}{*}{ Punta Tresino } & A & 3.16 & 0.06 & 0.06 & 0.10 & 0.61 & 0.15 & 0.37 & 0.35 & 5 & \\
\hline & & B & 22.90 & 0.4 & 0.26 & 0.57 & 1.6 & 0.94 & 1.18 & 8.88 & 37 & \\
\hline & & $\mathrm{C}$ & 2290 & 4 & - & 114 & 160 & 470 & - & - & 3038 & \\
\hline \multirow[t]{15}{*}{ Cilento coasr } & \multirow[t]{3}{*}{ Punta Licosa } & A & 3.04 & 0.07 & 0.09 & 0.09 & 0.77 & 0.13 & 0.33 & 0.12 & 5 & \\
\hline & & $\mathrm{B}$ & 22 & 0.5 & 0.36 & 0.52 & 2 & 0.8 & 1.08 & 0.29 & 28 & \\
\hline & & $\mathrm{C}$ & 2200 & 5 & - & 104 & 200 & 400 & - & - & 2909 & \\
\hline & \multirow[t]{3}{*}{ Acciaroli Bay } & A & - & 0.09 & 0.23 & 0.44 & - & 23 & 0.5 & - & 24 & This study (October 2010) \\
\hline & & $\mathrm{B}$ & - & 0.6 & 0.86 & 2.3 & - & 140 & 1.7 & - & 145 & \\
\hline & & $\mathrm{C}$ & - & 6 & - & 462 & - & 69,934 & - & - & 70,402 & \\
\hline & Acciaroli Marina & A & - & 0.39 & 26 & 0.96 & - & 1.58 & 2.25 & - & 32 & \\
\hline & & $\mathrm{B}$ & - & 2.63 & 99 & 5.02 & - & 9.57 & 7.14 & - & 123 & \\
\hline & & $\mathrm{C}$ & - & 26 & - & 1004 & - & 4783 & - & - & 5813 & \\
\hline & Casalvelino Bay & A & - & 0.15 & 0.33 & 0.60 & - & 0.31 & 0.86 & - & 2.23 & \\
\hline & & B & - & 0.99 & 1.23 & 3.11 & - & 1.88 & 2.72 & - & 9.92 & \\
\hline & & $\mathrm{C}$ & - & 10 & - & 622 & - & 939 & - & - & 1571 & \\
\hline & Casalvelino Marina & A & - & 0.72 & 11 & 0.86 & - & 4.25 & 2.88 & - & 20 & \\
\hline & & B & - & 4.9 & 44 & 4.48 & - & 25.7 & 9.16 & - & 88 & \\
\hline & & $\mathrm{C}$ & - & 49 & - & 895 & - & 12,849 & - & - & 13,794 & \\
\hline Gulf of Palermo (Sicily) & North West & A & - & - & 1.13 & 0.41 & 1.42 & 0.76 & - & 0.52 & 4 & Tranchina et al. (2008) \\
\hline & & $\mathrm{B}$ & - & - & 4.23 & 2.15 & 3.7 & 4.64 & - & 1.29 & 16 & \\
\hline & & $\mathrm{C}$ & - & - & - & 431 & 370 & 2323 & - & - & 3124 & \\
\hline & Palermo city port & A & - & - & 11.9 & 1.0 & 10.1 & 2.46 & - & 2.57 & 28 & \\
\hline & & B & - & - & 44.6 & 5.2 & 26.4 & 14.88 & - & 6.37 & 97 & \\
\hline & & $\mathrm{C}$ & - & - & - & 1049 & 2640 & 7444 & - & - & 9133 & \\
\hline & Oreto River & A & - & - & 3.9 & 1.51 & 7.15 & 1.94 & - & 1.63 & 16 & \\
\hline & & B & - & - & 14.7 & 7.93 & 18.6 & 11.74 & - & 4.05 & 57 & \\
\hline & & $\mathrm{C}$ & - & - & - & 1587 & 1860 & 5873 & - & - & 9320 & \\
\hline & Central Area & A & - & - & 2.6 & 0.9 & 3.85 & 1.32 & - & 0.78 & 9 & \\
\hline & & B & - & - & 9.6 & 4.8 & 10 & 8.03 & - & 1.93 & 34 & \\
\hline & & $\mathrm{C}$ & - & - & - & 964 & 1000 & 4016 & - & - & 5980 & \\
\hline & North Eastern & A & - & - & 1.4 & 0.99 & 1.38 & 0.99 & - & 0.84 & 6 & \\
\hline & & B & - & - & 5.3 & 5.21 & 3.6 & 5.99 & - & 2.09 & 22 & \\
\hline & & $\mathrm{C}$ & - & - & - & 1043 & 360 & 2999 & - & - & 4402 & \\
\hline Gulf of Termini Imerese (Sici & ly) & A & - & - & 1.3 & 0.74 & 0.61 & 0.74 & - & 0.87 & 4 & Tranchina et al. (2008) \\
\hline & & B & - & - & 4.9 & 3.88 & 1.6 & 4.48 & - & 2.16 & 17 & \\
\hline & & $\mathrm{C}$ & - & - & - & 776 & 160 & 2220 & - & - & 3156 & \\
\hline
\end{tabular}

but with different contamination profiles. Casalvelino Marina was mainly impacted by $\mathrm{Cd}$, whereas Acciaroli Marina by TBT. All other metals $(\mathrm{Cr}, \mathrm{Cu}, \mathrm{Ni}$ and $\mathrm{Pb})$ evidenced a contamination profile changing according to seasonality.

The EFs calculated for $\mathrm{Cd}, \mathrm{Cr}, \mathrm{Cu}, \mathrm{Ni}, \mathrm{Pb}$, and TBT were reported in Fig. 4. With the exception of $\mathrm{Pb}$, the highest $\mathrm{EFs}$ were observed after summer in marinas: from $144 \%$ for $\mathrm{Pb}$ up to of $23898 \%$ for $\mathrm{Cu}$ in Acciaroli Marina, and from $463 \%$ for Cd up to $10522 \%$ for $\mathrm{Cu}$ in Casalvelino Marina. Both marinas showed extremely high EFs especially for $\mathrm{Cu}$ (7074\% in Acciaroli Marina and 9550\% in Casalvelino Marina in March and 23898\% in Acciaroli Marina and
10522\% in Casalvelino Marina in October). High EFs were observed for $\mathrm{Ni}(253 \%)$ and $\mathrm{Cr}$ (541\%) in Casalvelino Bay that is influenced by the discharge of the drainage channels collecting water from farmland (Nziguheba and Smolders, 2008) and the overflow of Casalvelino wastewater treatment plant located next to the Alento River mouth (Fig. 1). In Fig. 4, the TBT EFs are available only for Acciaroli Marina according to Fig. 2F. The level of TBT significantly increased from March to October showing EF values of $749 \%$ and $3026 \%$, in that order, compared to the background level of Punta Licosa. 
Table 3

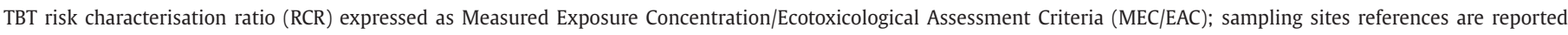
in Table 1 (S1-S17).

\begin{tabular}{|c|c|c|c|c|}
\hline Sampling sites & & RCRs & Sampling campaign & References \\
\hline \multirow[t]{6}{*}{ Gulf of Naples } & $\mathrm{S} 1$ & 3562 & July 1999 & Cicero et al. (2004) \\
\hline & $\mathrm{S} 2$ & 3158 & & \\
\hline & S3 & 3062 & & \\
\hline & S4 & 3256 & & \\
\hline & S5 & 2968 & & \\
\hline & S6 & 3006 & & \\
\hline \multirow[t]{2}{*}{ Gulf of Salerno } & S7 & 2094 & July 1999 & Cicero et al. (2004) \\
\hline & S8 & 2160 & & \\
\hline \multirow[t]{2}{*}{ Acciaroli Marina } & S9 & 18,683 & March 2010 & This study \\
\hline & & 68,782 & October 2010 & \\
\hline Acciaroli Bay & $\mathrm{S} 10$ & 310 & October 2010 & This study \\
\hline \multirow[t]{2}{*}{ Casalvelino Marina } & S11 & 1233 & March 2010 & This study \\
\hline & & 1404 & October 2010 & \\
\hline \multirow[t]{2}{*}{ Casalvelino Bay } & $\mathrm{S} 12$ & 167 & March 2010 & This study \\
\hline & & 314 & October 2010 & \\
\hline \multirow[t]{2}{*}{ Gulf of Policastro } & S13 & 1604 & July 1999 & Cicero et al. (2004) \\
\hline & S14 & 1482 & & \\
\hline \multirow[t]{2}{*}{ Gulf of Santa Eufemia } & S15 & 1466 & July 1999 & Cicero et al. (2004) \\
\hline & $\mathrm{S} 16$ & 1446 & & \\
\hline \multirow[t]{2}{*}{ North-Western Sicilian coasts and Ustica } & S17 & $600-5400$ & July-November 1999 & Chiavarini et al. (2003) \\
\hline & & & May-June 2000 & \\
\hline
\end{tabular}

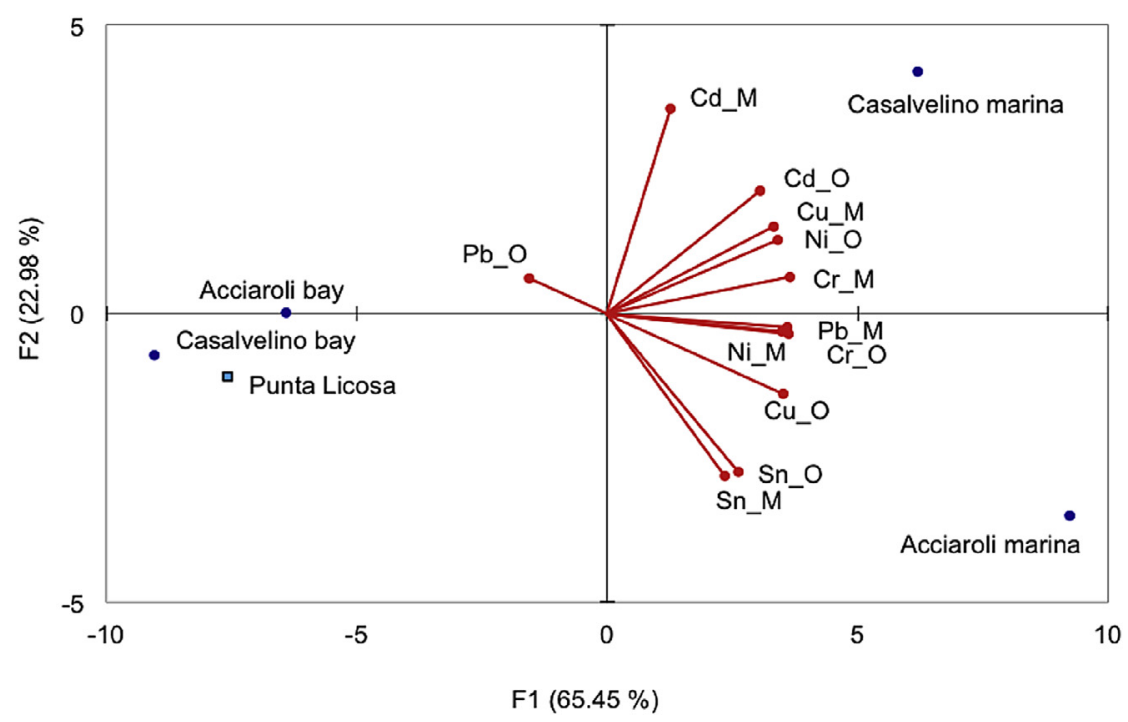

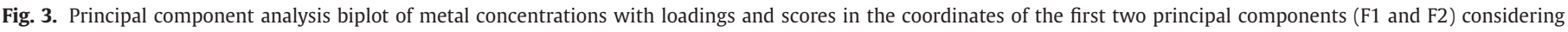
the sampling sites (_M = March 2010 sampling campaign;_O = October 2010 sampling campaign).

\section{Conclusion}

This was the first survey of $\mathrm{Cd}, \mathrm{Cr}, \mathrm{Cu}, \mathrm{Ni}, \mathrm{Pb}$ and TBT carried out on four sediment-sampling stations (Casalvelino Marina, Casalvelino Bay, Acciaroli Marina and Acciaroli Bay) from the Cilento coast. Data were compared to the contamination background levels of Punta Licosa reference site and further investigated calculating the relative enrichment factors on a seasonal basis as well as the risk characterisation ratios. Sediment samples evidenced a level of contamination generally increasing from March to October probably due the intensification of human activities along the coast during summertime. The quality of sediment from bays was similar to the reference site, while marinas showed significantly high levels of contamination. The values of risk characterisation ratios, considering both the single substanceand mixture-based approaches, highlighted the occurrence of potential threats. Nevertheless potential misinterpretation may result from the erroneous consideration of geogenic levels of elements, especially in active volcanic areas like Naples area, thus requiring the definition of specific regional guidelines for data interpretation

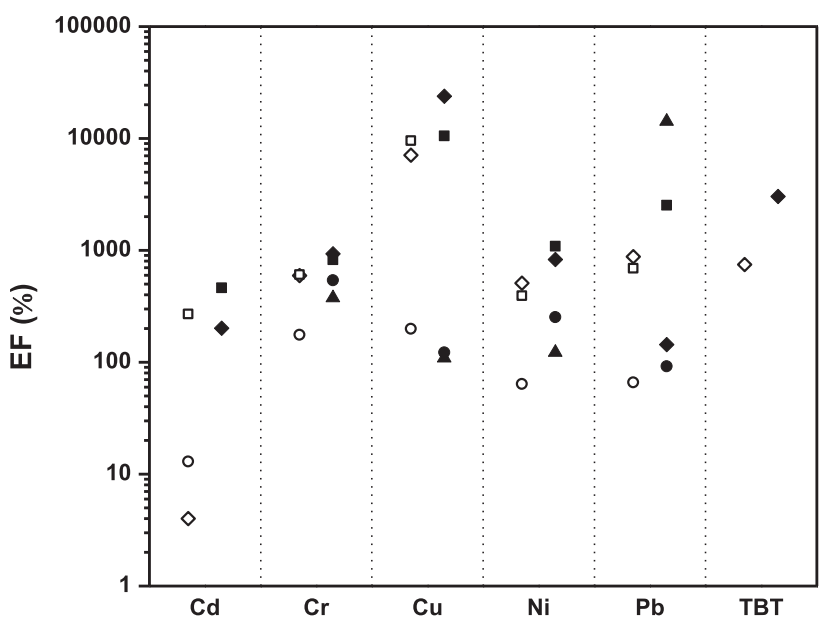

Fig. 4. Metal enrichment factors (EF) of sediment samples from Acciaroli Marina ( $\square$ March 2010; October 2010), Casalvelino Marina ( $\triangle$ March 2010; October 2010) Casalvelino Bay ( $\circ$ March 2010; • October 2010) and Acciaroli Bay (ム October 2010). 
on the basis of contextualised background levels. The database resulting from the review of sediment quality from other Southern Tyrrhenian Sea sampling stations reported an analogous state-ofthe-art, showing hot spots in coincidence of river mouths or port activities.

Further studies will be necessary to ascertain the background element concentrations along the Cilento coast, besides the currently available reference site of Punta Licosa, and to carry out ecotoxicological sediment characterisation to integrate the contamination-based assessment with a toxicity-based perspective.

\section{Acknowledgements}

This work was carried out in the framework of FARB 2009 project supported by Italian Ministry of Instruction, University and Research.

\section{Appendix A. Supplementary data}

Supplementary data related to this article can be found at http: //dx.doi.org/10.1016/j.chemosphere.2015.09.002.

\section{References}

Adelman, D., Hinga, K.R., Pilson, M.E.Q., 1990. Biogeochemistry of butyltins in an enclosed marine ecosystem. Environ. Sci. Technol. 24, 1027-1032.

Almeida, E., Diamantino, T.C., de Sousa, O., 2007. Marine paints: the particular case of antifouling paints. Prog. Org. Coat. 59, 2-20.

Arizzi Novelli, A., Losso, C., Libralato, G., Tagliapietra, D., Pantani, C., Volpi Ghirardini, A., 2006. Is the 1:4 elutriation ratio reliable? Ecotoxicological comparison of four sediment: water proportions. Ecotoxicol. Environ. Saf. 65, 306-313.

ARPAC, 2003. Progetto Sidimar 2001-2003. www.sidimar.tutelamare.it.

ARPAC, 2007. Progetto Sidimar 2003-2006. www.sidimar.tutelamare.it.

Bay, S.M., Weisberg, S.B., 2012. Framework for interpreting sediment quality triad data. Integr. Environ. Assess. Manag. 8, 589-596.

Canadian Sediment Quality Guidelines for the Protection of Aquatic Life, 1999 http: //www.ec.gc.ca/ceqgrcqe/English/Pdf/sediment summary table.htm.

Chakraborty, P., Ramteke, D., Chakraborty, S., Nath, B.N., 2014. Changes in metal contamination levels in estuarine sediments around India - an assessment. Mar. Pollut. Bull. 78, 15-25.

Chiavarini, S., Massanisso, P., Nicolai, P., Nobili, C., Morabito, R., 2003. Butyltins concentration levels and imposex occurrence in snails from the Sicilian coasts (Italy). Chemosphere 50, 311-319.

Choi, M., An, Y.-R., Park, K.J., Lee, I.-S., Hwang, D.-W., Kim, J., Moon, H.-B., 2013. Accumulation of butyltin compounds in finless porpoises (Neophocaena asiaeorientalis) from Korean coast: tracking the effectiveness of TBT regulation over time. Mar. Pollut. Bull. 66, 78-83.

Cicero, A.M., Nonnis, O., Romano, E., Finora, M.G., Bergamina, L., Graziosi, M. Balocchi, C., Focardi, S., 2004. Detection of Tributyiltin (Tbt) residues in Italian marine sediments. Chem. Ecol. 20, 319-331.

Diez, S., Abalos, M., Bayona, J.M., 2002. Organotin contamination in sediments from the Western Mediterranean enclosures following 10 years of TBT regulation. Water Res. 36 , 905-918.

Dowson, P.H., Bubb, J.M., Lester, J.N., 1992. Organotin distribution in sediments and waters of selected east coast estuaries in the UK. Mar. Pollut. Bull. 24, 492-498.

Ferraro, L, Sprovieri, M. Alberico, I, Lirer, F, Prevedello, L, Marsella, E, 2006. Benthic foraminifera and heavy metals distribution: a case study from the Naples harbour (Tyrrhenian Sea, Southern Italy). Environ. Pollut. 142, 274-287.

Ghekiere, A., Verdonck, F., Claessens, M., Monteyne, E., Roose, P., Wille, K., Goffin, A. Rappé, K., Janssen, C.R., 2013. Monitoring micropollutants in marine waters, can quality standards be met? Mar. Pollut. Bull. 69, 243-250.

ICRAM-APAT, 2007. Manuale per la movimentazione di sedimenti marini http:/ www.apat.gov.it.

IMO, International Maritime Organisation, 2001. International Convention on the Control of Harmful Anti-fouling Systems on Ships.

Kim, N.S., Shim, W.J., Yim, U.H., Ha Sung, Y., An, J.G., Shin, K.H., 2011. Three decades of TBT contamination in sediments around a large scale shipyard. J. Hazard. Mater 192, 634-642.

Kortenkamp, A., 2007. Ten years of mixing cocktails: a review of combination effects of endocrine-disrupting chemicals. Environ. Health Perspect 115, 98-105. http: //dx.doi.org/10.1289/ehp.9357.

Kotrikla, A., 2009. Environmental management aspects for TBT antifouling wastes from the shipyards. J. Environ. Manag. 90, S77-S85.
Krull, M., Abessa, D.M.S., Hatje, V., Barros, F., 2014. Integrated assessment of metal contamination in sediments from two tropical estuaries. Ecotoxicol. Environ. Saf. 106, 195-203.

Libralato, G., Losso, C., Arizzi Novelli, A., Citron, M., Della Sala, S., Zanotto, E., Cepak, F., Volpi Ghirardini, A., 2008. Ecotoxicological evaluation of industrial port of Venice (Italy) sediment samples after a decontamination treatment. Environ. Pollut. 156, 644-650. http://dx.doi.org/10.1016/j.envpol.2008.06.025.

Libralato, G., Losso, C., Avezzù, F., Volpi Ghirardini, A., 2009. Influence of salinity adjustment methods, salts and brine, on the toxicity of wastewater samples to mussels embryos. Environ. Technol. 30, 85-91. http://dx.doi.org/10.1080/ 09593330802505094.

Libralato, G., Volpi Ghirardini, A., Avezzù, F., 2010a. Seawater ecotoxicity of monoethanolamine, diethanolamine and triethanolamine. J. Hazard. Mater 176, 535-539. http://dx.doi.org/10.1016/j.jhazmat.2009.11.062.

Libralato, G., Volpi Ghirardini, A., Avezzù, F., 2010b. How toxic is toxic? A proposal for wastewater toxicity hazard assessment. Ecotoxicol. Environ. Saf. 73, 16021611. http://dx.doi.org/10.1016/j.ecoenv.2010.03.007.

Lofrano, G., Libralato, G., Acanfora, F., Pucci, L., Carotenuto, M., 2015. Which lesson can be learnt from an historical contamination analysis of the most polluted river in Europe? Sci. Total Environ. 524-525, 246-259.

Mamindy-Pajany, Y., Libralato, G., Roméo, M., Hurel, C., Losso, C., Volpi Ghirardini, A. Marmier, N., 2010. Ecotoxicological evaluation of Mediterranean dredged sediment ports based on elutriates with oyster embryotoxicity tests after composting process. Water Res. 44, 1986-1994. http://dx.doi.org/10.1016/j.watres.2009. 11.056

Nikolaou, A., Kostopoulou-Karadanelli, M., Lofrano, G., Meriç, S., 2009. Levels and toxicity of polycyclic aromatic hydrocarbons in marine sediments. Trends Anal. Chem. 28, 653-664.

Nziguheba, G., Smolders, E., 2008. Inputs of trace elements in agricultural soils via phosphate fertilizers in European countries. Sci. Total Environ. 39, 53-57.

OSPAR/ICES, 2004. Workshop on the Evaluation and Update of Background Reference Concentrations (B/RCs) and Ecotoxicological Assessment Criteria (EACs) and How These Assessment Tools Should Be Used in Assessing Contaminants in Water, Sediment and Biota.

Prato, E., Biandolino, F., Libralato, G., 2015. A toxicity scoring system for the 10 days whole sediment test with Corophium insidiosum (Crawford). Environ. Monit. Assess. 187, 180. http://dx.doi.org/10.1007/s10661-015-4405-X.

Prefecture, Shiga, 2001. Report on the Water Quality of Lake Biwa (Shiga Prefecture, Japan) http://www.pref.shiga.jp/biwako/koai/english/eng_04.htm.

Qiu, J.-W., Chan, K.M., Leung, K.M.Y., 2011. Seasonal variations of imposex indices and butyltin concentrations in the rock shell Thais clavigera collected from Hong Kong waters. Mar. Pollut. Bull. 63, 482-488.

Romano, E., Ausili, A., Zharova, N., Magno, C., Pavoni, B., Gabellino, M., 2004. Marine sediment contamination of an industrial site at port of Bagnoli, Gulf of Naples, southern Italy. Mar. Pollut. Bull. 49, 445-487.

Romano, E., Bergamin, L., Ausili, A., Pierfranceschi, G., Maggi, C., Sesta, G., Gabellino, M., 2009. The impact of the Bagnoli industrial site (Naples, Italy) on sea-bottom environment. Chemical and textural features of sediments and the related response of benthic foraminifera. Mar. Pollut. Bull. 59, 245-256.

Rzetala, M.A., 2015. Assessment of toxic metal contamination of bottom sediments in water bodies in urban areas. Soil Sediment. Contam. 24, 49-63.

Scancar, J., Zuliani, T., Turk, T., Milacic, R., 2007. Organotin compounds and selected metals in the marine environment of Northern Adriatic Sea. Environ. Monit. Assess. 127, 271-282.

Schipper, C.A., Rietjens, I.M.C.M., Burgess, R.M., Murk, A.J., 2010. Application of bioassays in toxicological hazard, risk and impact assessments of dredged sediments. Mar. Pollut. Bull. 60, 2026-2042.

Silva, P.V., Silva, R.A.R., Mendo, S., Loureiro, S., 2014. Toxicity of tributyltin (TBT) to terrestrial organisms and its species sensitivity distribution. Sci. Total Env. 466467, 1037-1046.

Sousa, A., Matsudaira, C., Takahashi, S., Tanabe, S., Barroso, C., 2007. Integrative assessment of organotin contamination in a southern European estuarine system (Ria de Aveiro, NW Portugal), tracking temporal trends in order to evaluate the effectiveness of the EU ban. Mar. Pollut. Bull. 54, 1645-1653.

Sprovieri, M., Sammartino, S., Manta, D.S., Marsella, E., Ferraro, L., 2006. Heavy metals in top core sediments from the southern Campania shelf (Italy): hints to define large-scale geochemical backgrounds. Chem. Ecol 22 (1), 65-91.

Tranchina, L., Basile, S., Brai, M., Caruso, A., Casentino, C., Miccichè, S., 2008. Distribution of heavy metals in marine sediments of Palermo Gulf (Sicily, Italy). Water Air Soil Poll. 191, 245-256.

Water Framework Directive EC Directive of the European Parliament and of the Council 2000/60/EC establishing a framework for community action in the field of water policy, Official Journal C513, 2000.

Wenning, R.J., Ingersoll, C.G., 2002. In: Summary of the SETAC Pellston Workshop on Use of Sediment Quality Guidelines and Related Tools for the Assessment of Contaminated Sediments; 17-22 August 2002; Fairmont, Montana, USA. Society of Environmental Toxicology and Chemistry (SETAC), Pensacola FL, USA. 